\title{
ETHNIC TRADITIONS OF CHILDREN UPBRINGING IN THE CHUVASH FAMILY AND THEIR REFLECTION IN THE LANGUAGE
}

\author{
Klara Pushkina ${ }^{1}$, Natalia Nikolaeva ${ }^{2}$, Elena Chekushkina ${ }^{3}$, Ekaterina Yakimova ${ }^{4 *}$ \\ ${ }^{1}$ Assoc. Prof. Dr., Chuvash State University, RUSSIA, Klara-608389@mail.ru \\ 2Senior lector, Chuvash State University, RUSSIA, nicknata75@inbox.ru \\ ${ }^{3}$ Assoc. Prof. Dr., Chuvash State University, RUSSIA, enarpi@mail.ru \\ ${ }^{4}$ Assoc. Prof. Dr., Chuvash State University, RUSSIA, katya-af@yandex.ru \\ ${ }^{*}$ Corresponding Author
}

\begin{abstract}
Parental responsibility in the upbringing of children is often noted in the works of the oral folk art of the Chuvash people. Much is said about parenting in fairy tales, proverbs and sayings, it is sung about in the songs so much. Parents pass on their life, work and spiritual and moral experience to their children. The power of the parents' educational influence on their children is emphasized in proverbs and sayings.
\end{abstract}

Children adorn life, strengthen the family and give joy. It is a child of a happy family who can become a support of the family, a protector of the native land and a future worker.

Etnopedagogy pays a special attention to mothers in the upbringing of children. As E.I. Sokolnikova notes in her monograph, "a Chuvash woman in a family is a binding beginning, she completely determines the general spiritual and moral mood of the family". Special position of a mother in parenting is explained by the difficulties of caring for young children and the important role of the mother's school in shaping the younger generation.

People have always emphasized the role of the mother in raising her daughter. This idea is reflected in the proverb: "Arçyn acha ashshĕ çumne çypăçat: hĕracha - amăshĕ çumne" (The son goes to the father, the daughter to the mother).

Nowadays, it is very important for Chuvash women to realize their historical role in the implementation of national educational goals, in the preservation of customs, traditions, language (native tongue is called mother tongue not without reason), costumes and in passing them on to the younger generation.

The solidarity of the Chuvash family, the national model of the family, admiration of parents and elders, and working traditions allow to involve children in the common problems and concerns of the whole family from an early age. The Chuvash child prepares himself for a hard life from the early years by the example of his parents.

Even today, for the sake of their children's future, the Chuvash people are ready to make sacrifices; they sincerely protect their children from all kinds of inconveniences and deprivations, sometimes overprotecting them. Extreme care for children "Epir kurnine achasen kurmalla an pultăr" (What we had to endure, may our children not get it) sometimes hurt. However, adherence to family values, traditions, worldviews of Chuvash people most often allow them to find a way out of any difficult situation, to find their place in life. The Chuvash attitude to the role of father and mother in raising children is quite clear: "Chun parakan atte-anne 
mar: ăs parakan atte-anne" (Parents are not those who gave soul, but those who gave mind).

The intra-family relations, which are characterized by an atmosphere of cordiality, mutual care and human intimacy, are most fruitful for the harmonious development of the personality. A relationship in which the adult selflessly gives the child the wealth of his or her soul without demanding anything in return, and the child enriches the adult with the healing purity of his or her emotions, means for children closeness to their parents. That is why children feel the need for friendly intra-family relations, good fatherly and motherly influence. Children grow up happy and prosperous when their parents understand and support them.

The aim of this study is to identify and describe the characteristics of educational ethnic traditions in the Chuvash family, their reflection in the language and to reveal the views on family education traditions in modern Chuvash families.

Keywords: Chuvash family, traditions of upbringing, proverbs and sayings, parents, children, personality formation, folk pedagogy.

\section{INTRODUCTION}

Since ancient times, family education is one of the main society problems. The functions of the family directly depend on society needs, therefore there is always a great interest in various manifestation features of the family educational function. The great family impact on a person can be traced from the day of the birth to death. A person does not appear with the birth of a child, but is formed only in human society. The first society of a newborn is the family: parents, grandparents, brothers and sisters, as well as other relatives.

The established traditions play an important role in the formation of the person; they strengthen relations between relatives and increase their influence on subsequent generations. Many traditions are constantly being improved, turning into rules, norms, peculiar unwritten laws of society.

Certain traditions are a kind of core of the family and the whole people, they allow you to save what the older generations have accumulated for a long time. All subsequent generations honor the traditions of their family and treat them with care, passing them on to other family members. Traditions include an educational character, and the experience that is embedded in these foundations is perceived by subsequent generations every time more and more naturally. The role of parental authority is great in this.

In oral folk art works of the Chuvash, as well as among many Turkic peoples, the responsibility of parents in raising children is described as very important. The role of parents in the formation of children is much discussed in fairy tales, proverbs and sayings, sung in songs.

\section{OPINIONS AND DISCUSSION}

The Chuvash people are convinced that children in the family are the immortality of their parents. Many other peoples held the same opinion. Children are the main value of the family. The birth of a child in the family strengthens the feelings of spouses with parental love, gives an impetus to self-education, daily work on oneself. Children perfect their parents. They teach adults altruism. In good, happy families, children care for their parents, as their parents do.

In the works of the oral folk art of the Chuvash people parental responsibility in the upbringing of children is noted. So, E.P. Chekushkina in the study "Turkic Art Traditions in the Chuvash Literature" gives parallels of proverbs and sayings among Turkic peoples (Chekushkina, 2004). Much is said about parenting in fairy tales, proverbs and sayings, it is sung about in the songs so much. Parents pass on their life, work and spiritual and moral experience to their children. The power of parents' educational influence on their children is emphasized in proverbs and sayings.

Of course, the character of intra-family relations has a strong influence on personality development. The most suitable for this definition are families with mutual care, closeness and respect for each other. The educational process in the family affects both children and adults. The closeness of the child with parents and other relatives forms such a relationship in which an adult transfers to the child the innermost riches of his (her) soul for nothing, while not receiving anything in return, and the child, taking all the best, in turn gives the older generations the purity of emotions, reveals them all secret doors of a child's soul. That is why children are in dire need of friendly relations within the family, great parental authority, and mutual 
understanding of family members. Naturally, such kind and cordial relations within the family have a positive effect on the formation of a personality in childhood.

The Chuvash people insist on every family to have children. "It is known that among the Chuvash, a childless family was not recognized as a full-fledged one" (Pushkina, 2006, p. 196). A newly married couple was given a kind of mandate at the wedding: lay down double and get up all three", i.e. they were charged with the duty of "multiply and replenish". It is no coincidence that wedding songs and blessings to the newlyweds also express a wish: "sak tully acha-păcha pultăr" (to have children full of bunks). Childlessness among the Chuvash was equated with blindness: "No children - no eyes".

Children are the foundation of the family, they fill life with joyful moments, continue the kin and pass it from generation to generation. In the Chuvash language there are proverbs and sayings that characterize the principles of family education, for example: "a gentle child means a happy life", "there is no death without reason, there is no happiness without a child". Children are an integral part of the family, future workers and defenders of the motherland. A quiet old age is predicted for those who have children. As the saying goes: "It's quiet without children, but it's bad for old age".

Children are the main family value, the birth of a child in the family binds the husband and wife with strong ties, a new special bond appears between them - parental love; the birth of a child makes parents more mature, intelligent people; children in the family, according to the Chuvash, are parental immortality.

The role of children in the process of education is described in the fundamental monograph "Ethnopedagogics of the Chuvash family" by E. I. Sokolnikova: "the moral image and character of young Chuvash people was determined by how children treated them. When someone came to the house for the first time, they judged his or her human qualities by how the child would meet the person. The one who truly loves children is not capable of meanness and cruelty, nor of lies and hypocrisy. This seemed the obvious truth. In order to win children's favor, adults had to show themselves in some way. The usual manifestations of a good attitude to children were a friendly address to them, inventing fun for children, teaching them games and participating in the games, treating them to something, etc. "children love him (her)"-these words served as the highest assessment of a person's spiritual kindness. The ability to find an approach to children was highly valued by the Chuvash" (Pushkina, 2006, p. 135).

Parents pass on their life, work and spiritual and moral experience to their children. The power of the parents' educational influence on their children is emphasized in proverbs and sayings: "Amăshne păh ta hĕrne il" (if you want to marry a girl, get to know the future mother-in-law), "Yvălsem ashshĕne hună" (sons are like father) etc.

Etnopedagogy pays a special attention to mothers in the upbringing of children. As E.I. Sokolnikova notes in her monograph: "a Chuvash woman in a family is a binding beginning, she completely determines the general spiritual and moral mood of the family". Special position of a mother in parenting is explained by the difficulties of caring for young children and the important role of the mother's school in shaping the younger generation (Sokolnikova, 1998, p. 75).

The appearance of the Chuvash woman was evaluated by the observations of $A$. A. Fuchs in the details given by her: beloved people should always be near, and they do not accept either ancient Greek or Pushkin's descriptions of women. There are a number of proverbs that mothers say to their children as wedding blessings: "Be always near each other", "Let it be fated to die you on the marital feather bed", "Let it be unbearable for you without each other" (Fuchs, 1840).

The exceptional role of the mother in the upbringing of children of both sexes is also characterized by Chuvash proverbs: "Amăshĕ matthur pulsan, ashshĕ uteriieh pulmasan ta, achisem ănaççĕ" (If the mother is a strong person, then children grow up to be good people even when the father is not particularly good). One should also pay attention to the peculiar form of a mystery about hops: "Ashshĕ - tÿrĕ: amăshĕ - kukăr: hĕrĕ - nachar: yvălĕ - usal" (Ashmarin, 1928-1950, V.2, p. 308) (Father is straight, mother is crooked, daughter is bad, son is evil). The riddle contains a quite conscious hint at the decisive role of mother in the formation of both daughter and son: if the mother is crooked, it is hard to expect any good things from her children - both daughter is bad, and son is evil. The hop rises, wraps a pole (straight father - support), but the final result of upbringing is still determined by the mother. This idea is confirmed in a certain way by the proverb: "Atte nacharri - incek: anne nacharri - wilĕm" (if the father is bad, it is a trouble, if mother is bad, it is death).

People have always emphasized the role of the mother in raising her daughter. This idea is reflected in the proverb: "Arçyn acha ashshĕ çumne çypăçat: hĕracha - amăshĕ çumne" (The son goes to the father, the daughter to the mother), "Ashshĕ vilni -çur tălăkh: amăshě vilni - pĕr tălăh" (father died - half orphan, mother 
Proceedings of SOCIOINT 2020-7th International Conference on Education and Education of Social Sciences, 15-17 June 2020

died - completely orphan), "Ashshĕ - allă, amăshĕ - pĕrre anchah" (fathers are fifty, and mother is only one).

Patriarch of the Chuvash people I.Ya. Yakovlev, noting the great role of the mother in children upbringing, wrote that women create an elusive atmosphere of feelings that the younger generation breathes. Justifying this, he pointed to the fact that the Chuvash women firmly adhere to the old customs and concepts. The founder of Chuvash pedagogy was right when he gave the mother a special role in preserving the national identity of his native people (Yakovlev).

Nowadays, it is very important for Chuvash women to realize their historical role in the implementation of national educational goals, in the preservation of customs, traditions, language (native tongue is called mother tongue not without reason), costumes and in passing them on to the younger generation.

It should be noted that the Chuvash mother after giving birth of children for the sake of their future often refuses herself. Youth is short-lived, then we must live in the name of children. "Çamrăklăh-văkhătlăh, văl kilet te kajat, malashlăh-achasenche, věsemshĕn purănmalla" (Youth comes and goes, the future is in children, it's worth living for them). The level of such goodwill continues today in many families, where the cult of grandparents, parents and children is scrupulously observed. Faith in the family rises in such families to the level of not only strong beliefs, but a kind of religion. The solidarity of the Chuvash family, the presence in it of a national model of the family, admiration for parents and elders, and labor traditions allow attracting children to the common problems and concerns of the whole family from an early age. A Chuvash child from an early age, following the example of parents, prepares himself for a difficult life. "Viççěri acha hărah uripé suhara tărat" (a three-year-old child is already helping adults) - they talked about Chuvash boys. (Pushkina, 2006, p. 58).

And today, for the sake of the future of the children, the Chuvash are ready to make sacrifices, they sincerely protect their children from all kinds of inconveniences and deprivations, sometimes taking care of them too much. The extreme concern for children, expressed in the proverb "Epir kurnine achasen kurmalla an pultăr" (may our children not endure what we had to endure on our shoulders) sometimes do harm. However, adherence to family values, traditions, and the worldview of the Chuvashs most often allow them to find a way out of any difficult situation, to find their place in life. The Chuvash attitude to the role of father and mother in raising children is quite clear: "Chun parakan atte-anne mar: ăs parakan atte-anne" (parents are not those who gave soul, but those who gave mind).

In the process of education, the role of the father is very important. V. A. Sukhomlinsky wrote that the father is twice a citizen. The spiritual kinship of father and child arises gradually. Children influence the formation of many positive qualities in the father. The pedagogical role of the father is considered both in terms of authority and in terms of his practical activities in education. The relentless educational activity, the work of the father, his social face, the level of culture, the attitude to the mother, the performance of household duties, his way of life - this is the ground on which his true authority - respect of children-arises. To do this, the father also needs to become a friend of the child - to be natural, to be able to communicate with it. A. S. Makarenko correctly noticed: "Father and son can be friends, they should be friends. But the father still remains the father, and the son remains the son, that is, the boy who needs to be brought up and who is brought up by the father, who thereby acquires some characteristics additional to his position as a friend" (Makarenko, 1984, V. 2, p. 206).

A man plays an important role in family education. For each father, respect from the children, first of all, means checking the qualities that are in him, evaluating his educational activities, and sometimes his whole life. The respect of children for fathers has always been seen as a sign of an unshakable and courageous people. The role of the father in the family, the atmosphere of trust and mutual respect are the main means of raising children in a patriotic spirit and love for work. But sometimes we observe that some fathers do not always imagine how their behavior affects the formation of the personality of the child.

In folk pedagogy, in fairy tales, songs, proverbs and sayings, it is noted that in raising children the father is more a moral factor (protects, demands, highlights his authority, etc.) and material (supports the family) rather than directly pedagogical one. For example: "do not walk all night long, do not disgrace the father's honest name", "my father has a good name, let his fame be forever", "if you do not want to listen to your father, you will listen to the executioner once". Despite the fact that the younger generation is growing up, for parents children will always remain children. Even adults who have already acquired their own families still listen to the words of their parents and follow their advice, because for them, parents are, first of all, authority and role model.

The most active educators in the Chuvash family are grandparents. The place of grandparents (the Chuvash words "asatte" (grandfather) and "asanne" (grandmother) literally translated as "great" or "elder father" and 
"great" or "elder mother") in folk education is determined by the fact that old people having rich experience, are the best educators of the younger generation - grandchildren.

The relationship between the old and the young generation is defined by the saying: "Vată çynna itles pulat', çamrăkkine vĕrentes pulat"' (the old person must be listened to, and the young one must be taught). There was an understanding among the people of the connection between the past and the present, between the old and the young: "Vattisene yuratmanni vĕttisene te yuratmast" (he who does not love the old, does not like children). The blessing at the wedding by the grandparents of the young spouses is considered a guideline for their further life together, i.e. a kind of recipe for arranging a family.

The founder of ethnopedagogy as a science, academician G.N. Volkov noted that "a particularly respectful attitude towards the old has always been a significant feature of the Chuvash, that is, the religious cult of dead ancestors was usually combined with the pedagogical cult of living grandfathers and greatgrandfathers". (Volkov, 1997, p. 401).

\section{RESEARCH}

In order to reveal the views on family education traditions in modern Chuvash families and to identify what pedagogical traditions are held in our days, we conducted a survey and testing of $2801-2$ year students of Chuvash state University. The questionnaire "family traditions" and the test "family biofield" were used. The results of cognitive component diagnostics in the respondents showed the following data:

$14 \%$ of respondents do not distinguish between such concepts as "traditions" and" family traditions" and related birthdays, national and religious holidays,

$8 \%$ of respondents found it difficult to define these concepts,

$78 \%$ of respondents answered these questions in a detailed and complete way.

Respondents were also asked about the introduction of new and revival of old traditions.

$2 \%$ of respondents had some difficulty answering this question,

$51 \%$ believe that their family has a fairly wide range of family traditions and rituals.

When asked whether respondents plan to preserve and increase family traditions in their future family, the following results were obtained:

$87 \%$ of respondents expressed the opinion that it is necessary to preserve family traditions,

$5 \%$ did not respond,

$8 \%$ believe that this is not necessary.

After studying the emotional-reflexive component of the "Family biofield" test, we came to the conclusion that most students have a favorable family atmosphere:

$85 \%$ of the family - stable favorable,

$12 \%$ - unstable favorable atmosphere,

$3 \%$ of respondents describe their family atmosphere as unstable.

By using the questionnaire "family traditions" we found out that the respondents were spending time with their parents for:

Morning jogging - 58 persons,

Gymnastics - 53 persons,

Sunday lunches - 198 persons,

Tourist trips - 90 persons,

Family competitions - 105 persons,

Joint viewing of TV programs - 74 persons,

Visiting relatives and close friends - 135 persons.

Our study showed that nowadays, parenting and maintenance of family traditions can be expressed in various forms such as joint sports activities (doing morning jogging and gymnastics), Sunday lunches and 
discussion of the events of the week, spending free time in nature, games of a competitive nature, such as volleyball, football, basketball etc., joint viewings of current TV programs and films with subsequent discussion.

Families with a negative family atmosphere were not found. This result can be explained by the fact that all our respondents were students of higher education institution and they initially came to study at the University from more prosperous families, the vast majority of the respondents' parents belong to the intellectual milieu. Thus, $97 \%$ of families are characterized by a favorable atmosphere, which contributes to the observance of traditions in these families.

Our experimental work was also aimed at identifying the attitude of respondents to the family. The results of the survey of students allowed us to draw the following conclusions:

$57 \%$ of respondents consider their parents to be the ideal mother and father;

More than $38 \%$ of respondents trust their parents;

$50 \%$ of students answered this question "not always"

For the majority of respondents the word "family" means "people who are close in spirit, who love, respect, and understand each other";

The following qualities are important for parents: kindness, love, understanding, modern views, support and mutual assistance, firmness and strictness.

\section{CONCLUSION}

Thus, the pedagogical activity of parents consists not only of establishing relationships between parents and children, but also between the parents themselves and family members. If the father protects the prestige of the mother, then this positively affects not only the authority of the mother, but also the father himself. Intrafamily relations, which are characterized by an atmosphere of cordiality, mutual care and human closeness are most fruitful for the harmonious development of the individual. That is why children feel the need for friendly intra-family relations, good paternal and maternal influence, and to be understood in the family.

Based on the foregoing, we conclude that the role of the Chuvash family home is great due to the great maternal and laconic fatherly love. "Living in the world without relations with relatives is difficult, because if there is no kindred, then there is nothing to lean against, there is no one to give advice". The Chuvash people have the opinion that a person is helpless without communication with relatives, parents, brothers and sisters, the homeland, native speech, because he finds himself in the position of a "lost sheep". Summing up, it is important to note that focused work to promote family traditions and family values contributes to the creation of strong families. Only in a strong family will traditions be maintained and respected, bringing up strong, strong and healthy children, worthy citizens of their homeland, on which the development of society depends

\section{REFERENCE LIST}

Ashmarin, N.I. (1928-1950) Dictionary of Chuvash Language: In 17 v. Kazan; Cheboksary, V.2.

Chekushkina, E.P. (2004) General Turkic artistic traditions in the Chuvash literature: PhD diss. Cheboksary, $185 \mathrm{p}$.

Fuchs, A.A. (1840) Notes on the Chuvash and Cheremis of the Kazan province. Kazan, 329 p.

Makarenko, A.S. (1984) Pedagogical works: in 8 vols. Moscow: Pedagogy, 400 p.

Pushkina, K.V. (2002) The role of educators in the harmonization of interpersonal relationships between spouses in a modern young family. / K.V.Pushkina // Family in Russia. № 1. 91-104 pp.

Pushkina, K.V. (2006) Harmonization of interpersonal relations of young spouses in the Chuvash family // Great ethnopedagogical mission of women: collection of articles of international scientific-practical conf. of Cheboksary, 189-196 pp.

Pushkina, K.V. (2008) Influence of a parental family on the relationship of the spouses (in Russian) // Family. 
Proceedings of SOCIOINT 2020- 7th International Conference on Education and Education of Social Sciences, 15-17 June 2020

State. Society: Collection of articles of scientific and practical conf. Moscow-Cheboksary, 103-110 pp.

Pushkina, K.V.; Nikolaeva, N.V. (2017) Traditions of upbrining in the modern Chuvash family (in Russian) // Problems of modern pedagogical education. Series: Pedagogy and Psychology 55(6): a collection of scientific works. Yalta,161-167 pp.

Sokolnikova, E.I. (1998) Ethnopedagogy of Chuvash family: history theory, practice (XIX-XX cc.): Doctoral thesis. Cheboksary, $358 \mathrm{p}$.

Volkov, G.N. (1997) Ethnopedagogy of the Chuvash people. Moscow, 441 p.

Yakovlev I. Ya. Essay in 4 volumes. Ed.2. manuscript. 